\title{
THE APPLICATION OF SECTION 17 OF THE INVESTMENT COMPANY ACT OF 1940 TO PORTFOLIO AFFILIATES
}

\section{INTRODUCTION}

Section 17 of the Investment Company Act of $1940,{ }^{1}$ for many years a hazard principally to persons planning direct transactions with investment companies, now stands as an obstacle also to corporations planning mergers with one another, should an investment company hold five percent of either's outstanding voting securities. The Securities and Exchange Commission (SEC) not long ago served notice that it will seize on the circumstance of statutory affiliation of one party with an investment company to justify scrutiny which otherwise would clearly lie outside its power. That the SEC reads too broadly the extent of review called for under the Act, that it misinterprets section 17 in applying it to such transactions at all, ${ }^{2}$ that the Act's legislative history evidences no intention on the part of Congress to regulate such conduct, ${ }^{3}$ and that the examination of corporate activity on so fortuitous a basis is without support in policy, ${ }^{4}$ may all be justifiable observations but provide little comfort to the practitioner who seeks the consummation of a deal with a minimum of delay occasioned by legal proceedings. The policymaker's problem here lies in protecting investment company shareholders without at the same time providing undue interference with mergers and like transactions.

The root of these problems is that in some respects the SEC's interpretation of section 17 and in some respects the very language of section 17 are much broader than the purpose of the legislation as evidenced by the congressional committee hearings on the proposed Act. Briefly stated, that purpose was the prohibition of self-dealing, whether direct or indirect, on the part of investment companies' insiders, and the protection of investment company shareholders from any loss in the value of their shares that might be caused by such dealing. ${ }^{5}$

However, section 17 (a) has been construed to have substantially wider implications. This section provides:

It shall be unlawful for any affiliated person or promoter of or principal underwriter for a registered investment company (other than a company of the character described in section $80 \mathrm{a}-12$ (d) (3) (A) and (B) of this title [involving

\footnotetext{
115 U.S.C. $\$ \S 80 \mathrm{a}-1$ to -52 (1970) [hereinafter referred to as the Act].

2 See notes 112-13 infra \& accompanying text.

3 See notes 96-102 infra \& accompanying text.

${ }^{4}$ See text accompanying note 133 infra.

5 See notes 96-102 infra \& accompanying text.
} 
underwriters owned entirely by investment companies-an exception not relevant for our purposes]), or any affiliated person of such a person, promoter, or principal underwriter, acting as principal-

(1) knowingly to sell any security or other property to such registered company or to any company controlled by such registered company, unless such sale involves solely (A) securities of which the buyer is the issuer, (B) securities of which the seller is the issuer and which are part of a general offering to the holders of a class of its securities, or (C) securities deposited with the trustee of a unit investment trust or periodic payment plan by the depositor thereof;

(2) knowingly to purchase from such registered company, or from any company controlled by such registered company, any security or other property (except securities of which the seller is the issuer); or

(3) to borrow money or other property from such registered company or from any company controlled by such registered company (unless the borrower is controlled by the lender) except as permitted in section $80 a-21(b)$ of this title. ${ }^{6}$

The impact of this section is mitigated somewhat by the availability of administrative exemption under section $17(\mathrm{~b}) .^{7}$ That mitigation, however, is in turn limited by the SEC's interpretation of section $17(\mathrm{~b})$; the Commission would seek to protect all parties to proposed section 17 (a) transactions, rather than the investment company alone. ${ }^{8}$ Additional hazards for those coming into contact with

615 U.S.C. $\$ 80 \mathrm{a}-17$ (a) (1970). The "except" and "unless" provisions of this subsection suggest misleadingly a substantial degree of leeway in avoiding its application; in point of fact, not only are they narrow by their terms, but their effect is countered by other (frequently more stringent) sections of the Act. See, e.g., id. $\S \S 80 a-22$ to $-23,-26$ to -27 . Note, however, should be made of the "ordinary course of business" exception made by $\$ 17(\mathrm{c})$, applying to merchandise sales and purchases and to lessor-lessee relationships. See $i d$. $\$ 80 a-17(\mathrm{c})$.

$7 I d$. $\$ 80 \mathrm{a}-17$ (b) (requiring the SEC to issue orders exempting proposed transactions "if evidence establishes that- $(1)$ the terms of the proposed transaction, including the consideration to be paid or received, are reasonable and fair and do not involve overreaching on the part of any person concerned; (2) the proposed transaction is consistent with the policy of each registered investment company concerned, as recited in its registration statement and reports filed under [the Act]; and (3) the proposed transaction is consistent with the general purposes of [the Act]").

A further exemption route (of particular desirability, possibly, where antecedent application for exemption under $\$ 17$ (b) was overlooked, cf. notes 144-45 infra \& accompanying text) may be afforded by $\$ 6(\mathrm{c})$ of the Act, which grants the SEC farreaching discretionary powers. 15 U.S.C. \$80a-6(c) (1970). However, the applicant under $\S 17$ (b) may be able to assert a stronger claim to exemption.

8 The statutory language does not specify the intended beneficiary of the SEC's scrutiny. Where the SEC would read the prohibition to bar "overreaching [of 
investment companies, even though nothing cognizable as a "sale" or "purchase" under section 17 (a) is involved, may be found in section 17 (d) and rule $17 \mathrm{~d}-1$ promulgated thereunder, ${ }^{9}$ which operate to impose a similar regulatory scheme in a much wider variety of situations.

The breadth of these sections resides in their use of the term "affiliated person," which is defined in section 2(a)(3) of the Act as follows:

"Affiliated person" of another person means (A) any person directly or indirectly owning, controlling, or holding with power to vote, 5 per centum or more of the outstanding voting securities of such other person; (B) any person 5 per centum or more of whose outstanding voting securities are directly or indirectly owned, controlled, or held with power to vote, by such other person; (C) any person directly or indirectly controlling, controlled by, or under common control with, such other person; (D) any officer, director, partner, copartner, or employee of such other person; (E) if such other person is an investment company, any investment adviser thereof or any member of an advisory board thereof;

anyone] on the part of anyone concerned," others would read it as limited to "overreaching [of the investment company] on the part of anyone concerned." See notes 9, 46, 133-35 infra \& accompanying text.

9 15 U.S.C. $\$ 80 a-17$ (d) (1970) ; 17 C.F.R. $\$ 270.17 d-1$ (1972). Subsection 17 (d) makes unlawful the effecting of "any transaction" involving joint participation with affiliated investment companies or companies controlled by them "in contravention of such rules and regulations as the Commission may prescribe for the purpose of limiting or preventing participation by such registered or controlled company on a basis different from or less advantageous than that of such other participant." The SEC's rule, which establishes an antecedent-exemption procedure, quite arguably goes beyond the statute to a significant degree, in making it unlawful for persons standing in the affected relationship to each other to "participate in, or effect any transaction in connection with, any joint enterprise or other joint arrangement or profit-sharing plan," 17 C.F.R. \$270.17d-1(a) (1972), and in defining the latter to embrace

any written or oral plan, contract, authorization or arrangement, or any practice or understanding concerning an enterprise or undertaking whereby [persons standing in the affected relationship] have a joint or a joint and several participation, or share in the profits of such enterprise or undertaking ....

Id. $\$ 270.17 \mathrm{~d}-1$ (c). The SEC has thus far escaped or survived challenge, however, on the validity of its rule. See notes $13-14,27-33,75-78$ infra \& accompanying text.

The SEC, in interpreting the standard for exemption under rule $17 \mathrm{~d}-1$, unlike under $\S 17(\mathrm{~b})$, has tended to restrict scrutiny to the impact of the proposed arrangement upon the investment company alone. Compare American Hawaiian S.S. Co., SEC Investment Company Act Release No. 5675 (May 13, 1969) (exemption granted under rule 17d-1; impact upon other parties ignored), with Gould v. American Hawaiian S.S. Co., 331 F. Supp. 981 (D. Del. 1971) (proxy rules heid violated; arguable unfairness to other parties brought out in this action based on same facts). It can be argued from $\$ 17$ (d)'s concern simply that the investment company not participate "on a basis different from or less advantageous than" others, that a similarly-restricted concern for the investment company alone should be inferred in $\$ 17(\mathrm{~b})$. That different language is used need not be taken to imply different concerns: the simplest explanation for the apparent discrepancy would appear to be that the Act's draftsmen recognized that to speak of a party's basis of participation in a purchase or sale transaction, or to speak of the fairness of the consideration, etc., in a joint participation, would be to achieve facial congruity at the expense of verbal integrity. 
and $(F)$ if such other person is an unincorporated investment company not having a board of directors, the depositor thereof. ${ }^{10}$

Clause (B) should not always be applied to section 17 (a); it is hard to imagine how a company affiliated with an investment company in this way (hereinafter referred to as a "portfolio affiliate") could be supposed to be in a position to deal with the investment company to the latter's detriment.11 Thus, it would seem that the mere fact of such an affiliation provides scant justification for presuming the likelihood of any form of unfair influence such as would require SEC scrutiny. An argument might therefore be made that so far as section $17(a)$ is concerned, clause (B) can be read out of the definition of "affiliated person" on the ground that it only applies "unless the context otherwise requires" 12 - not in the case of portfolio affiliates.

This Comment will, in its next three parts, examine the SEC's interpretation of section 17. The Commission's approach will first be laid out objectively and in greater detail, with a discussion of some practical problems created by this approach, in part II. In part III, the validity of that approach will be judged in light of the background of section 17. And in part IV, the desirability of that approach

1015 U.S.C. \$ 80a-2(a) (3).

11 But cf. SEC v. Talley Indus., Inc., 399 F.2d 396, 403 (2d Cir. 1968), cert. denied, 393 U.S. 1015 (1969) ("[C]ongress could have thought that downstream affiliation also involved some danger that the investment company's stockholders might be put upon for the benefit of other stockholders of the affiliate.").

There is, however, a far more plausible explanation for the inclusion of clause $(B)$, if one considers the second-level affiliations embraced by $\S 17$ 's proscriptions of certain acts whether performed by "any affiliated person... or any affiliated person of such a person." If the first-level affiliation with the investment company is "downstream," that is, if the affiliate is controlled by, or owned in excess of $5 \%$ by, the investment company, the statement made in the text with respect to the portfolio affiliate's inability to harm the investment company is likely to remain accurate, whether or not further affiliations (downstream or otherwise) with the portfolio affiliate enter the picture. But if the first-level affiliation with the investment company is "upstream" in nature, that is, if the affiliate is a director or $5 \%$ owner of, or otherwise in a position to influence, the investment company, then it is apparent that-in the absence of clause (B) or of the application of $\$ 17$ to second-level affiliates-the first-level affiliate could escape the prohibition against self-dealing simply by consummating such transactions through a company which, by virtue of his $5 \%$-or-greater ownership, he influences. It is only the clause (B) company in the latter position-the downstream affiliate of a first-level upstream affiliate of an investment company - that appears to have been intended as an object of regulation by the Act's draftsmen, cf. notes 108-11 infra \& accompanying text, and it is similarly the position of this Comment that the downstream-of-upstream affiliate's-but not the portfolio affiliate's-regulation can be supported on policy grounds. See generally notes 134-37 infra \& accompanying text.

1215 U.S.C. $\$ 80 \mathrm{a}-2$ (a) (1970). Given the remedial nature of the Act, however, stuch an interpretation is unlikely to succeed. The "unless the context otherwise requires" phrase, although its dimensions are not clear, may most likely have been meant as a means for aiding the SEC in reaching abuses that are arguably outside the literal definitions of $\$ 2(\mathrm{a})$. Although the same phrase appears in the definitional sections of the Securities Act of 1933 ( $\$ 2,15$ U.S.C. $\$ 77 \mathrm{~b}$ (1970)) [hereinafter referred to as the 1933 Act] and the Securities Exchange Act of 1934 ( $\$ 3(a), 15$ U.S.C. \$78c(a) (1970)) [hereinafter referred to as the 1934 Act], neither the legislative history, nor the cases under these two acts (nor under the $1940 \mathrm{Act}$ ) illuminate the reach of the phrase. 
compared to other possible approaches will be weighed on policy grounds; proposals will be suggested to make section 17 regulation more consistent with those policies. Finally, because legislative and administrative solutions may not respond quickly enough to resolve tomorrow's case, the fifth part of this Comment will offer some suggestions on structuring transactions in ways that will entail minimal contact with section 17 .

\section{The SEC's Application of Section 17}

The case law for the most part accords a wide reach to section 17 . Rightly or not, well-advisedly or not, it poses a formidable handicap to any who would challenge it. Most of the cases, however, are SEC opinions of unpersuasive authority: memorandum decisions supporting grants of exemptions under section 17 (b), rule $17 d-1$, and, occasionally, section 6(c), which gives the SEC a substantial amount of discretion to grant exemptions from the Act. These opinions are characterized, especially in more recent years, by dry recitations of the facts presented in the applications for exemption, followed by psittacistic findings of compliance with the applicable standards for exemption. The applications are very often unopposed, and in the occasional cases where a jurisdictional challenge might be appropriate (on the grounds, for example, that section 17 did not apply to the transaction proposed, or that statutory affiliation was not present) it is very often disregarded altogether by the applicant or raised only lukewarmly. Following a practical or expedient approach, it may be the case that "[a]pplicants do not concede that Section 17(d) of the Act and Rule 17d-1 thereunder are applicable to the proposed transactions, but seek relief thereunder in order to eliminate any question as to full compliance with Section 17(d) of the Act." 13 Resort to the courts is infrequent, most likely because of time pressures and because of the SEC's decision to grant an exemption and thus render the jurisdictional ambiguities matters of much less moment. ${ }^{14}$ The effect of all this is to give the would-be challenger of the SEC's interpretation rather little encouragement. (It is unknown, of course, how many section 17 violations in the past may have escaped the scrutiny of the SEC in the absence of any applications for exemption. Although it may be unlikely, therefore, that the SEC would initiate litigation, still if its interpretations of section 17 were to be applied in any court action by a strike-suitor, the portfolio affiliate who disputes the SEC's reading will have a difficult position to maintain.)

13 Axe-Houghton Stock Fund, Inc., SEC Investment Company Act Release No. 5098, at 4 (Sept. 21, 1967).

14 In E.I. du Pont de Nemours \& Co., 34 S.E.C. 531 (1953), the SEC announced its claim to a wider jurisdiction under $\$ 17$ only after its finding that an exemption would be granted in that case. For a description of the SEC's narrower jurisdiction prior to this decision, see note 113 infra \& accompanying text. 


\section{A. Section 17 in Focus: The Talley Litigation}

The recent merger of Talley Industries and General Time Corporation (GTC) attracted the attention of many commentators, as it dramatized the potential for interference inherent within section $17 .^{15}$ Talley embarked upon its acquisition plan in the last days of 1967, and indicated its intentions to American Investors Fund, Inc. (the Fund), a mutual fund which, by virtue of its holding nine percent of Talley's voting shares, was a statutory affiliate of Talley. ${ }^{16}$ The Fund, after reviewing its data on GTC, acquired a substantial number of GTC shares through Talley's broker. This transaction was consummated without any collateral agreement between the Fund and Talley as to the voting of the shares at the forthcoming annual stockholders meeting of GTC. Indeed, the Fund made the purchase of shares because, in its evaluation, the potential success of the merger made such an investment attractive. Above all, it is apparent that the Fund's own self-interest dictated it buy the shares and vote them as it did.

GTC rejected Talley's proposal of a friendly merger, and brought an action ${ }^{17}$ against Talley and the Fund alleging violation of section 17 (d) of the Act ${ }^{18}$ and rule $17 \mathrm{~d}-1{ }^{19}$ thereunder, which bar affiliates from engaging in transactions as joint participants with an investment company without prior SEC approval. This suit was ultimately dismissed for lack of standing. ${ }^{20}$ In the meantime, Talley, without any assistance or participation from the Fund, embarked on a proxy campaign in order to gain control of GTC's board of directors. In conjunction with this, and pursuant to rule $17 \mathrm{~d}-1$, Talley was required to apply for SEC approval of its concurrent acquisition of GTC stock by itself and the Fund. ${ }^{21}$ The Commission rebuffed Talley's assertion

15 Analysis, Securities Transactions by Investment Company Affiliates, BNA SEc. REg. \& L. REP., Apr. 1, 1970, at B-1 [hereinafter cited as BNA Analysis]; Dudley, Transactions With Affiliates, in PLI Mutual Funds 357 (1970); Routier, Affiliated Person and Section 17, in PLI MuTual Funds 369 (1970); Kroll, The "Portfolio Affiliate" Problem, PLI 3D INST. ON SEc. Reg. 261 (1972). (1970).

16 See Investment Company Act of 1940 \$2(a)(3), 15 U.S.C. $\$ 80 a-2(a)$ (3)

17 General Time Corp. v. American Investors Fund, Inc., 283 F. Supp. 400 (S.D.N.Y.), aff'd sub nom. General Time Corp. v. Talley Indus., Inc., 403 F.2d 159 (2d Cir. 1968), cert. denied, 393 U.S. 1026 (1969).

1815 U.S.C. $\$ 80 \mathrm{a}-17$ (d) (1970).

1917 C.F.R. $\$ 270.17 \mathrm{~d}-1$ (1971).

20283 F. Supp. at $402-03$.

Cf. Bangor Punta Corp. v. Chris-Craft Indus., Inc., 337 F. Supp. 1147, 1154 (S.D.N.Y. 1971) (counterclaim brought by successful contender in take-over contest, for increased acquisition costs allegedly incurred as a result of loser's violations of $\$ 17$ (a), dismissed; counterclaimant held "well beyond the pale of protection fairly intended by $\left.[\$ 17(\mathrm{a})]^{\prime \prime}\right)$.

A second GTC suit, seeking injunctive relief for alleged violations of the SEC's proxy rules, was dismissed on the merits. General Time Corp. v. Talley Indus., Inc., 283 F.' Supp. 832 (S.D.N.Y.), aff'd, 403 F.2d 159 (2d Cir. 1968), cert. denied, 393 U.S. 1026 (1969).

21 See SEC v. Talley Indus., Inc., 399 F.2d 396, 400 (2d Cir. 1968), cert. denied, 393 U.S. 1015 (1969). 
that section 17(d) did not apply, and denied Talley's application for exemption as well, finding a prohibited joint arrangement and "no warrant for granting retroactive approval of the transactions effected in such violation." 22 On the basis of this determination, made April 19,1968 , GTC made a further request to Judge Tyler to enjoin Talley from voting its shares at the upcoming GTC shareholders' meeting, but once again was unsuccessful. ${ }^{23}$ The election was held as scheduled, with preliminary reports indicating Talley's nominees had won control. ${ }^{24}$

On May 1, 1968, the SEC brought an action under section 17 (d) to require the withdrawal of Talley's votes cast at the meeting. ${ }^{25}$ Talley won a clear victory in the district court, where Judge Wyatt chided:

The SEC allowed itself to be persuaded, unwisely as it seems to me, to throw its weight on the side of one of two contending factions in a situation where the stockholders of Time [GTC] - the real parties in interest-were being given an opportunity, as Judge Tyler found, in the exercise of corporate democracy to make an "informed choice". ${ }^{26}$

Judge Wyatt viewed the SEC's independent civil action as not bound by the Commission's findings, and went on to find that Talley had effected no "transaction" in which the fund was a "joint or joint and several participant." ${ }^{2 \pi} \mathrm{He}$ wrote:

Fund has no financial interest of any sort in the shares of Time bought by Talley nor any agreement, understanding or commitment of any sort ever to have any such interest. There is no conceivable way by which Fund can be in any way affected financially by the purchase by Talley of the shares. ${ }^{28}$

He went on to satisfy himself not only that the language of section 17 (d) did not apply to the concurrent stock purchases by the Fund and Talley but that the legislative history clearly indicated the section was aimed at very different situations. ${ }^{29}$

22 See id. at 401.

23 See id.

$24 I d$.

25 SEC v. Talley Indus., Inc., 286 F. Supp. 50 (S.D.N.Y.), rev'd, 399 F.2d 396 (2d Cir. 1968), cert. denied, 393 Ư.S. 1015 (1969), decree on remand aff'd, 407 F.2d 65 (2d Cir. 1968), cert. denied, 393 U.S. 1026 (1969).

26 Id. at $57-58$.

$27 I d$. at $58-59$.

$28 \mathrm{Id}$. at 58 .

29 Id. at $59-60$. 
On appeal, the moral victory was the SEC's, although Talley retained its practical success. ${ }^{30}$ Judge Friendly, unlike Judge Wyatt, was deferential to the SEC's determination and refused to cast the agency in the same role as a private litigant. He ruled that the congressional policy behind section 43(a) of the Act, making the Commission's determination of factual questions conclusive if supported by substantial evidence, applied to the case, although this section (relating to direct review of SEC orders) was not expressly applicable by its terms. ${ }^{31}$ Judge Friendly went on to find there was substantial evidence, buttressed by the SEC's "knowledge of the unspoken customs of the business world," that:

[D] evelopments may well have brought Industries and Fund into a "combination" not clearly envisioned by either at the outset . . . . [A]fter [Fund president George] Chestnutt had seen Industries spend over $\$ 8,300,000$ in acquiring the 205,837 shares purchased in the special offer and on February 21 and 23 , he was no longer a completely free agent as to the 210,000 shares Fund had purchased, on Talley's recommendation, for about $70 \%$ of that price. Experienced business men must have known at the outset that such a situation might arise. ${ }^{32}$

Judge Friendly upheld the validity of rule $17 d-1$ 's requiring advance application for exemption in all cases. $\mathrm{He}$ reasoned that the SEC could well have determined that to specify a narrower set of circumstances in which advance application must be made, might fail to accomplish the purpose of section $17(\mathrm{~d})$, given the infinite varieties in which an investment company's participation in a joint undertaking could be different from that of an affiliate. ${ }^{33}$ Friendly balked, however, at endorsing the relief asked for by the SEC. He left it to the district court to formulate an injunction consistent with the Second Circuit's admitted failure

to perceive how the interest of Fund's stockholders would be advanced by such provisions as requiring Industries and Fund to withdraw votes cast at the April 22 stockholders' meeting of General Time and enjoining further voting by them. . . Whether or not General Time had sufficient standing to direct judicial attention to the violation of $\S 17(\mathrm{~d})$, an issue on which we have no occasion to pass,

30 SEC v. Talley Indus., Inc., 399 F.2d 396 (2d Cir. 1968), cert. denied, 393 U.S. 1015 (1969).

$31 \mathrm{Id}$. at 403. See 15 U.S.C. $\$ 80 \mathrm{a}-42$ (1970).

32399 F.2d at 404.

33 Id. at 404-05. 
protection of the interests of its management in retention in office is not an objective of that section. ${ }^{34}$

Since, given the novelty of the application of section $17(d)$ to the fact situation, Talley and the Fund could not be regarded as having deliberately flouted the statute, there was no reason, Judge Friendly held, to frame an injunction going beyond what was necessary to protect the Fund's shareholders. ${ }^{35}$ Such a minimal order was handed down by Judge $W y a t t$ on remand ${ }^{3 B}$ he enjoined Talley and the Fund from future transactions violative of section $17(\mathrm{~d})$, but provided that certain acts, among them the voting by each of its GTC shares, would not be deemed violative of section 17 (d) provided there was no consultation between Talley and the Fund concerning those acts. Wyatt's order also included "elaborate provisions designed to insure Fund equal or preferential treatment with respect to any sale of the GTC shares." ${ }^{37}$

GTC appealed, asking that the votes cast by the Fund and Talley be ordered withdrawn. The Second Circuit refused to discuss the merits of GTC's request, holding that it had no standing to appeal the order. ${ }^{38}$ It noted, however, that its endorsement of the limited relief was "limited to the special circumstances of this case-an excusable violation of $\S 17$ (d) based on what we considered to be an overly literal although not unnatural reading of its words." 39 The result, then, is that even though Talley and the Fund weathered the litigation well enough for their practical purposes, it remains unclear how great a reach will be accorded section 17 (d) in the future, and whether future violations will be as innocent or excusable in the view of the courts.

With the Supreme Court's denials of certiorari in the various actions under section $17(\mathrm{~d}),{ }^{40}$ the seating of GTC's new directors took place on January 13, 1969, and the expected merger arrangements were announced shortly thereafter. But the merger could not be completed for more than a year. It was now clear, of course, that the SEC would have to be reckoned with, and the merger agreement was conditioned on the obtaining of an exemption under section 17 (b) for the exchange, pursuant to the merger, of the Fund's GTC shares for shares of Talley. An application accordingly was filed. Talley's

$34 I d$. at 405.

35 Id. at $405-06$.

36 Judge Wyatt's decree is unreported, but is described in the Second Circuit's opinion in the appeal from his decree. See SEC v. General Time Corp., 407 F.2d 65, 68 (2d Cir. 1968), cert. denied, 393 U.S. 1026 (1969).

37 Id.

38 Id. at $70-72$.

$39 \mathrm{Id}$. at 70 n.6.

40 General Time Corp. v. Talley Indus., Inc., 393 U.S. 1026 (1969), denying cert. to 403 F.2d 159 (2d Cir. 1968); General Time Corp. v. SEC, 393 U.S. 1026 (1969), denying cert. to 407 F.2d 65 '(2d Cir. 1968); General Time Corp. v. SEC, 393 U.S. 1015 (1969), denying cert. to 399 F.2d 396 (2d Cir. 1968). 
argument (raised only tangentially in its brief, ${ }^{41}$ which perhaps reflected a realistic appraisal of the point's likelihood of success) that the exchange did not constitute a transaction subject to section $17(a)$, was quickly rebuffed by the SEC. ${ }^{42}$ The Commission cited, in support of its position, a line of its decisions-all involving mergers arranged by the investment companies involved or by companies controlled by those companies-holding mergers subject to section 17.33 In only one earlier reported decision had the SEC applied section 17 to a merger where the investment company was not in a position of control and did not participate in the merger negotiations; that case, Aetna Life Insurance Co., ${ }^{44}$ was not cited by the SEC in Talley, and could provide little authority, because jurisdiction was conceded by the applicant there with the goal of obtaining an exemption as expeditiously as possible. ${ }^{45}$

The SEC went on to apply its interpretation of the standards of section 17 (b) to the Talley proposal, and found the merger terms unfair to GTC shareholders. Talley increased, as the SEC demanded, the conversion ratio for the Talley Series B convertible preferred stock to be offered the GTC shareholders, and the SEC's approval was finally obtained on February 10, 1970.

Although the rationale for the proceeding, as for the Investment Company Act itself, was to protect the investment company's shareholders, the SEC's opinion has relatively little to say about the Fund's participation in the proceeding. Even granting that the Fund's participation in the acquisition of GTC shares may have been prompted in consultation with Talley, it was clear that the Fund had not negotiated with Talley or with GTC on the exchange ratio, and was certainly not being overreached by an insider in a position to influence the Fund. Indeed, if the Fund's votes would be essential to approval of the merger, as they were to the election of the new directors, the relationship was precisely to the contrary. The SEC might well have based its decision upon its view that the Fund's holding of nine percent of GTC's shares, and just six percent of Talley's, would cause the Fund to be a net beneficiary of any exchange ratio more favorable to the GTC shareholders. The opinion leaves the impression, however, that the SEC was operating with an intention to decree an absolutely fair price, and not necessarily to forward the investment company's interest. Indeed, other decisions have produced results disadvantageous

41 Applicant's Post-Hearing Memorandum at 57-60, Talley Indus., Inc., SEC Investment Company Act Release Nos. 5953 (Jan. 9, 1970), 5977 (Feb. 10, 1970), in [1969-1970 Transfer Binder] CCH FED. SEc. L. REP. IT 77,774, 77,783.

42 Talley Indus., Inc., SEC Investment Company Act Release No. 5953 (Jan. 9 , $1970)$, in [1969-1970 Transfer Binder] CCH FED. SEC. L. REP. $\{77,774$, at 83,785. 43 Id. at 83,785 n.5.

44 SEC Investment Company Act Release No. 4082 (Nov. 19, 1964), in [19641966 Transfer Binder] CCH FED. SEC. L. ReP. \77,159.

45 See BNA Analysis, supra note 15, at B-7. 
to the investment companies involved. ${ }^{46}$

The effect, then, of a statute the purpose of which was the protection of investment company shareholders from loss through insider self-dealing, ${ }^{47}$ was to delay for two years a transaction in which there was no palpable wrongdoing of any sort. Although aware of Talley's intention to acquire GTC by merger, the Fund engaged in no negotiations with Talley and, aside from voting its GTC shares, took no part in Talley's proxy contest to place its candidates on GTC's board. The Fund was treated no differently from other GTC (or Talley) shareholders and indeed, the only connection the Fund had with Talley was its ownership of more than five percent of Talley's outstanding voting shares.

Talley is certainly the most dramatic case of this expanded application of section 17 of the Act, but it is by no means the only situation which might bring such a result. A similar result might well obtain wherever section 17 (a) is brought into play by the fact that a corporation statutorily affiliated with an investment company undertakes to merge, through an exchange of shares (or, quite possibly, as will be treated briefly in the final section of this Comment, through other means), ${ }^{48}$ with another corporation even a single share of whose stock is held by the same investment company. ${ }^{49}$ In 1958, there were more than 150 investment company portfolio holdings of the requisite size; ${ }^{50}$ in 1969 , more than $350 ; 51$ and for the first financial quarter of 1972 , it seems the pattern prevails. $^{52}$ Even if SEC action appears unlikely in the many mergers that these companies might engage in, the specter of private suits can not be dismissed so readily.

46 See, e.g., Bowser, Inc., SEC Investment Company Act Release No. 4842 (Feb. 8, 1967), in [1966-1967 Transfer Binder] CCH FED. SEC. L. REP. I 77,435.

47 See notes 96-102 infra \& accompanying text.

48 See text accompanying notes $148-53$ infra.

49 If the investment company owns any stock in the company with which an affiliate merges by means of an exchange of stock, the affiliate, in the SEC's view, sells to the investment company by giving shares of its stock to the investment company in exchange for those shares of the target company the investment company owns. The shares received by the affiliate from the investment company constitute a purchase by the affiliate under this interpretation. Under $\$ 17(\mathrm{a})$, both sales of stock to, and purchases of stock from, an investment company by one of its affiliates are prohibited.

50 Wharton School of Finance \& Commerce, A Study of Mutual Funds, H.R. ReP. No. 2274, 87th Cong., 2d Sess. 24 (1962) [hereinafter cited as WHaRToN REPORT].

51 BNA Analysis, supra note 15, at B-2.

52 Statistics on portfolio holdings of the 286 investment companies with $\$ 25$ million or more in assets indicate 283 instances of portfolio affiliation. See ARTHUR IIPPER CORP., INSIGHT: BOOK Two-PORTFOLIo HOLDINGS . . OF Funds vii, xiii, 1-163 (1st quarter 1972). Such statistics are not readily available for the 126 investment companies with between $\$ 10$ and $\$ 25$ million in assets, see id. Book ONEHoldings aNd TRANSACTIONS xiii, or for smaller companies. Five-percent-or-greater holdings in portfolio companies are related more to an investment company's goals and policies than to its size. See id. Book Four-Portrolio PERSPECTIVE 373-79. Additionally, the dimensions of the problem may be aggravated, if a fund complex's holdings must be aggregated, see note 58 infra. 


\section{B. The Problem of Portfolio Affiliation}

The threshold problem in this area is the identification of instances of portfolio affiliation. Determining what falls within the definition is not so difficult under section 2(a) (3) of the 1940 Act as is, for example, determining ownership of certain percentages of equity securities for purposes of sections 13(d) or 16(a) of the 1934 Act.53 While questions may arise under the 1934 Act with respect to whether convertible securities, ${ }^{54}$ contracts to purchase securities at some future time, ${ }^{55}$ or puts and calls ${ }^{56}$ are included within the definition of "equity securities" under various reporting requirements, the Investment Company Act's definition of "affiliated person" in clause (A) and in clause (B) of section 2(a) (3)-the focus of concern in portfolio affiliation problems-turns on the notion of a "voting security." 57 The latter term is given an unambiguous operational definition in section 2(a) (42) as being "any security presently entitling the owner or holder thereof to vote for the election of directors of a company." 58

The more difficult problem is a practical, not a legal, one: discovering that an affiliation exists. Since the SEC receives from registered investment companies each year a total of several thousand required filings, it seems unreasonable to require operating companies to inspect all of them to determine when an affiliate relationship exists. ${ }^{59}$ While the 1934 Act's section 13 (d) ${ }^{60}$ in its recently-amended form, requires stockholdings of more than five percent to be reported to the company concerned, as well as to the SEC, this is not a completely adequate answer either. It is unclear, for one thing, whether section 13(d) filings would be required of a fund-holding complex or of a group of investment companies under single advisership. Bath Industries, Inc. v. Blot ${ }^{61}$ suggests that such filings would be required,

5315 U.S.C. $\$ \S 78 \mathrm{~m}$ (d), 78p(a) (1970).

$5 \pm$ See Chemical Fund, Inc. v. Xerox Corp., 377 F.2d 107 (2d Cir. 1967) (over $10 \%$ of convertible debentures held not the equivalent of $10 \%$ of "any class of equity security" where conversion would yield less than $3 \%$ common stock).

55 Cf. Booth v. Varian Associates, 334 F.2d 1 (1st Cir. 1964), cert. denied, 379 U.S. 961 (1965) (future contract to purchase securities held to be an "equity security").

56 See Silverman v. Landa, 306 F.2d 422 (2d Cir. 1962) (call options held not to be the equivalent of "equity securities").

5715 U.S.C. $\$ \S 80 \mathrm{a}-2$ (a) (3) (A), (B) (1970).

5815 U.S.C. $\$ 80 \mathrm{a}-2$ (a) (42) (1970).

Whether shares held by two investment companies under a single adviser would be added together for purposes of determining affiliation is less clear, but, since the Act's concern with affiliation is grounded in patterns of influence and control (see notes 84-89 infra \& accompanying text), the answer most in accord with the Act's purposes is that they should. While this question has not been ruled on definitively, many of those who are active in the area assume this would be the result. Kroll, supra note 15 , at $267-69$.

59 See 36 SEC ANn. ReP. 136 (1970).

6015 U.S.C. $\$ 78 \mathrm{~m}(\mathrm{~d})(1970)$.

61427 F.2d 97 (7th Cir. 1970), aff'g 305 F. Supp. 526 (E.D. Wis. 1969). See generally Comment, Section 13(d) and Disclosure of Corporate Equity Ownership, 119 U. PA. L. REv. 853 (1971). 
however, and certainly the SEC could exert its rulemaking authority to bring about a closer interface between the duties placed on stockholders by the 1934 Act's section 13(d) and the needs of portfolio companies under the 1940 Act's sections 2(a)(3) and 17. Further, a failure to make an accurate filing under section 13(d) would not harm the investment company under section 17 (which prohibits the affiliate from doing certain things) but could have seriously harmful consequences for the affiliate; this, perhaps, might likewise be remedied by an SEC rule, here excusing violations by the portfolio affiliate and imposing personal liability upon the fund's management, where proper filing has not been made. The most significant drawback to reliance on section 13 (d) is that not all companies are subject to the 1934 Act's filing requirements. ${ }^{62}$ Indeed, it is in the case of smaller, nonreporting companies that many of the substantial holdings that give rise to portfolio affiliation may be expected, because it is possible to hold a greater percentage of their stock with a small investment. In the absence of SEC action requiring reporting by investment companies to all statutory affiliates, ${ }^{03}$ perhaps the most feasible solution for many portfolio companies would be to subscribe to a service that reports the holdings of investment companies on a periodic basis.

Some companies may well prefer not to be portfolio affiliates, given the obstacles this could pose to one's financial activities. It seems most unlikely that one could ban outright the acquisition of one's securities by investment companies without incurring de-listing by the exchanges. But it may be possible to secure the cooperation of the investment company in a sale to the portfolio affiliate, at the then-prevailing market price, of all securities in excess of what would, after the purchase, be five percent of the affiliate's outstanding voting securities. An exemption under section $17(\mathrm{~b})$ would have to be obtained, of course, but this seems unlikely to pose a problem. Certainly, a sale of securities at the current market price would be likely to meet the "reasonable and fair" standard which is required by that section for an exemption. In the event the investment company is uncooperative, little could readily be done to end the affiliation, it seems, and in any event nothing could be done to prevent its recurrence. One technique which may be resorted to by the unwilling portfolio affiliate in extremis would entail the following steps (and, it should be clear, substantial costs) : first, the purchase of more than three percent of the investment company's outstanding voting securities (taking into account the fact that in the case of an open-end company, this figure is subject to constant increase); and then, the issuance and

62 Under the 1934 Act, many smaller companies are not subject to registration unless they are listed on an exchange. See 15 U.S.C. $\$ \$ 78 l(\mathrm{a}),(\mathrm{g})(1970)$.

63 A system that identifies statutory affiliates, however, still leaves an element of uncertainty about merger activities between an affiliate and a nonaffiliate company. The affiliate does not know if the same fund that owns $5 \%$ or more of its shares also owns any shares of the nonaffiliate; ownership of even a few such shares could trigger $\$ 17$ scrutiny. 
sale of additional securities of the portfolio company in sufficient number to reduce the investment company's present holdings below what will be the five percent mark. Because of the "cross-ownership" (defined in section 20 (c), as two companies each owning three percent or more of the other's stock) created in the first step, the investment company-when placed on notice of the cross-ownership-will be barred under the Act from making any further purchases of the portfolio company's shares. ${ }^{64}$ It may be feasible to finance the purchase of the investment company's shares with the proceeds of the sale of the affiliate's shares. Once again, however, it should be noted that techniques such as that suggested can only serve to eliminate instances of affiliation, not to prevent their recurrence.

Affiliation once established, the range of transactions proscribed by section 17 is substantial. Section 17 (a) (1), proscribing sales directly to the investment company or companies controlled by it, is not often individually a problem-most likely because the investment company can usually purchase what it desires on the market with little difficulty. ${ }^{65}$

Section 17 (a) (2) has been applied to the purchase of the portfolio affiliate's own securities, both pursuant to a tender offer ${ }^{66}$ and otherwise, ${ }^{67}$ and to the purchase of third companies' securities ${ }^{68}$ of of patents and licenses ${ }^{69}$ as well, but the SEC met with defeat in attempting to apply it to the redemption of debentures substantially according to terms set out in the instrument redeemed. ${ }^{70}$

Sections 17 (a) (1) and (2), operating in tandem, have been applied not only to mergers through the exchange of securities, as in the Talley case, but also to the conversion of preferred stock into common, ${ }^{71}$ and of bonds into common, ${ }^{72}$ to the exchange of new warrants for old, ${ }^{73}$

6415 U.S.C. $\$ 80 \mathrm{a}-20$ (c) (1970).

65 One application of this section that might not be obvious, however, is to the exercise of warrants; see Axe-Houghton Stock Fund, Inc., SEC Investment Company Act Release No. 5122 (Oct. 5,1967 ).

On this, and on the releases cited in notes $66-77$ infra, see Kroll, supra note 15 , at $273-89$.

66 Scripps-Howard Inv. Co., SEC Investment Company Act Release No. 5175 (Nov. 27, 1967).

67 Chamberlain Mfg. Corp., SEC Investment Company Act Release No. 6394 (Mar. 22, 1971).

68 Great Am. Ins. Co., SEC Investment Company Act Release No. 4989 (June $13,1967)$.

69 E.I. du Pont de Nemours \& Co., SEC Investment Company Act Release No. 6526 (May 17, 1971).

70 SEC v. Sterling Precision Corp., 393 F.2d 214 (2d Cir. 1968), aff'g 276 F. Supp. 772 (S.D.N.Y. 1967).

${ }^{71}$ Axe-Houghton Fund A, Inc., SEC Investment Company Act Release No. 5150 (Oct. 30, 1967).

72 Missouri-K.-T.R.R., SEC Investment Company Act Release No. 5182 (Dec. $4,1967)$.

73 Value Line Special Situations Fund, SEC Investment Company Act Release No. 6621 (July 15, 1971). 
and to the amendment of a loan agreement in effecting the subordination of certain debentures. ${ }^{74}$

Section 17(d), particularly as interpreted through the SEC's rule 17d-1 (which, it will be recalled, the Second Circuit has given at least a qualified endorsement to), ${ }^{75}$ has more flexibility in its application than any of the others. It has been applied to a registered joint public offering of the affiliate's securities to be made by both the investment company and the affiliate. ${ }^{70}$ Although there is no case presenting the situation, it might be supposed to apply to the concurrent acceptance of a tender offer by both investment company and portfolio affiliate. It has been applied to the mere concurrent holding of securities in a third company by both investment company and affiliate. ${ }^{77}$ And, of course, it was applied in SEC $v$. Talley Industries, Inc. ${ }^{78}$ to the concurrent acquisition of a third company's securities.

Since most of the above-enumerated transactions, unlike the exchange of shares in the Talley case, as a matter of course involve negotiations between the investment company and the affiliate, it seems less disturbing that the SEC should be permitted to oversee those transactions. Yet the departure from the purpose of protecting the investment company's shareholders is just as clear-whether there is negotiation or not-whenever it is the investment company that in fact is in a position to influence the affiliate. Under the state of the current case law, however, it is not possible to avoid the operation of section 17 , on this reasoning.

\section{Background For the Interpretation of Section 17}

Both the underlying purposes and the language of section 17 raise serious questions with respect to the validity of the SEC's current interpretation. In any event, the changes in the generation since its passage mandate a reassessment of the SEC's position.

\section{A. The Purposes Underlying Section 17}

The purposes of section 17, as understood by both those who passed the statute as well as those who were first confronted with it, seem to

74 Greater Washington Indus. Invs., Inc., SEC Investment Company Act Release No. 3759 (Aug. 29, 1963).

75 SEC v. Talley Indus., Inc., 399 F.2d 396 (2d Cir. 1968), cert. denied, 393 U.S. 1015 (1969).

${ }^{66}$ First Provident Co., SEC Investment Company Act Release No. 6400 (Mar. $23,1971)$.

77 Wisconsin Sec. Co., SEC Investment Company Act Release No. 5708 (June $12,1969)$. A revision of rule 17d-1, considered by the SEC, see 32 Fed. Reg. 14,96870 (1967), but never adopted, would, among other changes, have decreed a violation if either the portfolio affiliate or the investment company held $2 \%$ or more of the securities of a third party any of whose securities were held by the other. It seems likely that Judge Friendly was influenced by this proposal in $S E C v$. Talley Industries, Inc. See 399 F.2d 396, 403 n.7 (2d Cir. 1968), cert. denied, 393 U.S. 1015 (1969). The proposed revision was withdrawn, 34 Fed. Reg. 18,954 (1969).

78399 F.2d 396 (2d Cir. 1968), cert. denied, 393 U.S. 1015 (1969). 
have been the prevention of self-dealing on the part of those managing and controlling investment companies and the inhibition of pyramiding through the scrutiny of intercompany transactions in investment company holding systems. The SEC's broadly-conceived study of investment trusts ${ }^{79}$ discussed at great length the problems of insider selfdealing to the detriment of investment companies' shareholders: of loans made to insiders, never repaid, and inadequately secured if at all ${ }^{80}$ of the use of investment companies as disposal grounds, at inflated prices, for securities otherwise unmarketable; ${ }^{81}$ of the manipulation of investment company portfolios to suit the purpose of the insiders. "T2 "These various transactions," the SEC reported, "were permeated with conflicting interests, and many were characterized by the absence of arm's-length dealing and by opportunities for overreaching." 83 The drafters of the Investment Trust Study were, of course, concerned with the potential for abuse in mergers and consolidations, but only where the investment company itself was undergoing reorganization. ${ }^{84}$ For the most part, however, even this concern was based on the finding that shifts in the control of investment companies often occurred as a result of the desire of the unscrupulous to place themselves in positions affording opportunities for self-dealing. ${ }^{85}$ Furthermore, when a portion of the Study transmitted to Congress only several months after the passage of the Investment Company Act, and not printed until $1942,{ }^{86}$ did at one point concern itself with abuses in intercompany transactions in securities, it was almost exclusively because of the role such transactions played in the shifting of control of investment companies. ${ }^{87}$ This may properly be construed as evidence in support of the position that so far as section 17 is concerned, only the upstream affiliation under section $2(\mathrm{a})(3)(\mathrm{A})$, and not the portfolio affiliation of section 2(a) (3) (B), should be considered. Some concern was shown at this point for the role which investment companies could play in enabling their sponsors or managers to influence portfolio company affairs, ${ }^{88}$ but for the most part, the Study's material on investment companies' "control and influence over industry" 89 escaped inclusion in the "abuses and deficiencies" portion of the Study. Indeed, the last volume of the Study, in which the material on invest-

79 SEC, Report on the Study of Investament Trusts and InVestment ComPANIES (1939-1942) [hereinafter cited as InVESTMEnT TRUST Study].

80 See id. pt. 3, at 22, 2640-720.

81 Id. $22,2581$.

82 Id. 2486-87.

83 Id. 22.

84 See generally id. 1017-561.

85 Id. 1024.

86 Id. ch. 7.

87 Id. 2794.

88 Id. 2624.

89 Id. pt. 4. 
ment company influence appears, ${ }^{90}$ contains little of the disapproving language so conspicuous in the earlier volumes. The Study pointed out that according to the nature of the interests which the investment company seeks to serve, such influence could redound to either the profit or the detriment of the portfolio company. ${ }^{91}$ It thus noted that investment companies could in some cases occasion the payment of improvident dividends by their portfolio affiliates in efforts to bolster their own financial positions, ${ }^{92}$ and further related a number of instances in which investment companies had shown themselves inclined to involve themselves in the reorganization of portfolio affiliates. ${ }^{93}$ But the Study did not, on balance, find occasion to score investment companies. It observed that what abuses there had been by virtue of participation by investment companies in reorganizations and recapitalizations "were not indigenous to reorganizations controlled by investment companies but rather were common to most reorganizations . . . " 94 It then went on to find a significant value in investment companies' participation in such affairs:

Investment companies can perform, aside from the function of furnishing the required additional capital, the vital function of supplying expert analysis and appraisal of the merits of the plans of the reorganization particularly with respect to those situations in which a governmental agency does not have jurisdiction to pass on or advise with respect to the fairness of the plan. Thus they can be the articulate effective protector of the public minority stockholders against unfairness and over-reaching. Experience indicates that they can occasionally also facilitate reorganizations by accepting less than their complete legal rights though at the same time making a profit, a course extremely difficult for the small individual investor. ${ }^{95}$

Consistent with the Study's focus of interest, there is no reference to investment companies' voting as stockholders on proposed mergers or participating in exchanges of shares in their consummation. In summary, the SEC's Study that led to the development of investment company legislation gives no ground for concluding that a transaction such

$90 \mathrm{Id}$.

91 Id. 27.

92 Id. $27-28$.

93 Id. 29-37, 306-31.

94 Id. 370 .

95 Id. 370-71. For a recent case of an investment company's forgoing certain of its legal rights in order to see a financially-embarrassed portfolio company continue as a going concern, see Greater Washington Indus. Invs., Inc., SEC Investment Company Act Release No. 3759 (Aug. 29, 1963). Here the investment company requested an SEC exemption to allow the subordination of its loan to the portfolio company. 
as that engaged in by the fund in the Talley case was a matter of serious concern.

The history of the Act's progress through Congress supports the same conclusion. Although the industry denounced the bill when introduced as "neither livable nor workable," 96 it endorsed the prohibition of self-dealing, ${ }^{97}$ and that section survived with essentially the same proscriptions (although with arguable differences in the scheme of exemptions) ${ }^{98}$ into the compromise between the SEC and the industry that became the Investment Company Act of 1940. David Schenker, chief counsel for the SEC's study of investment trusts, testified, with reference apparently to the original bill's section 17 :

[T] his bill says that you cannot sit on both sides of the table when you are dealing with an investment trust. If you are a director or officer or manager or controlling [note that Mr. Schenker did not say, "controlled"] person you cannot sell any property to an investment trust, because you are sitting on one side representing yourself where you have a pecuniary interest, and you are sitting on the other side representing the investment trust; and we say that fundamentally that should not be permitted. ${ }^{99}$

Mr. Schenker, testifying at a later point in the Senate's hearings, described such transactions as "the only thing" proscribed by section 17 , and explained that section as premised on the fiduciary relationship obtaining between the insider and the investment company ${ }^{100}$ - a relationship quite clearly not obtaining in the case of a portfolio affiliate. Section 17 seems to have been clearly understood, then, both in the hearings on the bill ${ }^{101}$ and in the committee reports, ${ }^{102}$ to be simply a prohibition of conventional self-dealing.

What criticism of investment companies there had been before the SEC's Study was also focused not on influence over portfolio companies, but rather on self-dealing on the part of insiders. ${ }^{103}$ Indeed, this view was emphasized in reading the Act's section 17, by law review

96 Hearings on $S .3580$ Before a Subcomm. of the Senate Comm. on Banking \& Currency, 76th Cong., 3d Sess., pt. 2, at 345 (1940) (Investment Trusts \& Investment Companies) [hereinafter cited as Senate Hearings].

97 E.g., id. 1055-56.

98 Cf. SEC v. Talley Indus., Inc., 399 F.2d 396, 405 (2d Cir. 1968), cert. denied, 393 U.S. 1015 (1969). See also note 33 supra \& accompanying text.

99 Senate Hearings, supra note 96, pt. 1, at 130-31.

$100 \mathrm{Id} .256$.

101 Id. pt. 4, at 1116 (hearings on S. 4108, the compromise bill).

102 Senate Comm. on Banking \& Currency, Investment Company Act of 1940 \& INVESTMENT Advisers Act of 1940, S. ReP. No. 1775, 76th Cong., 3d Sess. 7,14 (1940); House CoMm. ON InTERstate \& Foreign CoMmerce, InVEstanent Company Act of 1940 \& INVESTMent Advisers ACT of 1940, H.R. Rep. No. 2639, 76th Cong., 3d Sess. 9, 17-18 (1940).

103 For an account of, and excerpts from, prior criticism of the investment company industry, see InVESTMENT TRUST Study, supra note 79 , pt. 3, at 39-49. 
commentators of the time ${ }^{104}$ and by the SEC itself for many years, ${ }^{105}$ and it is the same interpretation that present-day commentators and judges most often attach to this section. ${ }^{106}$ Judge McLean, for example, wrote in SEC v. Sterling Precision Corp., where he rejected the Commission's contention that a redemption of securities pursuant to the terms upon which they were originally issued, could be a "purchase" subject to section 17 (a) (2): "The unsupervised self-dealing which Congress intended to prevent would seem to be dealing of the sort which involves negotiations or bargaining between the two companies." ${ }^{107}$

\section{B. The Language of the Act}

It is clear by hindsight, however, that the language of section 17 has not been successful in delineating Congress' apparent purpose, and it is not surprising that this should be the case. Senator Taft at the 1940 Senate hearings confessed some confusion with respect to its import:

Frankly, it would take all afternoon to study section 17 to find out what it means, before I begin to criticize it. You define what would be an affiliated person, or any affiliated person of such a person acting as principal; and then you say that no affiliated person of an affiliated person of a registered investment company shall sell any stock to the company. Is that the English of it? It is certainly pretty hard to understand what this section does prohibit and what it does not. ${ }^{108}$

The bill's principal draftsman was willing to attempt an explanation. Mr. Schenker replied to the senator:

What we tried to say-and it is a little complicated-is that no officer, director, or controlling person, no partner of his in a firm in which he is a partner, and no company which

104 E.g., Jaretzki, The Investment Company Act of 1940, 26 WASH. U.L.Q. 303, 317-19, 321 (1941) ; Thomas, The Investment Company Act of 1940, 9 GEo. WASH. L. Rev. 918, 937 (1941); Comment, The Investment Company Act of 1940, 50 Y $\mathrm{ALE}$ L.J. 440, 449 (1941) ("[Section 17] is directed at a rather cruder type of peculation . ") ; Note, The Investment Company Act of 1940, 41 Colvur. L. REv. 269, 288-89 (1941); Federal Legislation, Investment Company'Act of 1940, 29 GEo. L.J.' 614, 623-24 (1941). Note, Regulation of Investment Companies, 88 U. PA. L. REv. 584, 592, 606 (1940), appeared after publication of the Investment Trust Study, but before the Senate hearings were held; it called for conventional self-dealing prohibitions.

105 See Hearings on Powers, Duties \& Functions of the SEC before a Subcomm. of the Honse Comm. on Interstate \& Foreign Commerce, 82d Cong., $2 \mathrm{~d}$ Sess., pt. 1, at 384-85 (1952).

106 E.g., The Mutual Fund Industry: $A$ Legal Survey, 44 Notre DaMe Law. $732,789,802(1969)$.

107276 F. Supp. 772, 774 (S.D.N.Y. 1967).

108 Senate Hearings, supra note 96, pt. 1, at 261. 
he controls, shall have the right to sell property to the investment trust.

The use of the term "affiliated person" is an attempt in a shorthand way to spell out those situations that I have enumerated. Maybe we have not said it, but I think we have. ${ }^{109}$

Today's problem, of course, is that Mr. Schenker's "shorthand" has been construed to embrace not only the enumerated situations, but also, via clause (B) of section 2(a) (3), the portfolio affiliate. The language, however, is unambiguous and unyielding here, and unless resort can successfully be had to the "unless-the-context-otherwise-requires" condition placed on the applicability of section 2(a)'s definitions, ${ }^{110}$ the legislative history therefore may not be used to interpret the statute and thereby remove the portfolio affiliate from the ambit of section 17.111

The SEC's reading is not so well supported by the Act's language, when it finds an exchange of securities pursuant to a merger to constitute a "purchase" and a "sale" within the meaning of sections 17 (a) (1) and (2). The argument seems persuasive that Congress used those words with full knowledge and approval of the SEC's "no-sale" doctrine applied to the issuance of securities in the course of a merger (in that context, obviating the need to file a registration statement under the Securities Act of 1933). ${ }^{112}$ This argument in fact held sway with the SEC itself until 1953.113

109 Id. Mr. Schenker's reference to companies controlled by investment company insiders may fairly suggest a concern as well with companies merely infuenced by such insiders. Compare $\$ 2(a)(3)(B)$ of the Act (influence) with $\$ \$ 2(a)(3)(C)$, 2(a) (9) (control). See also note 11 supra.

110 Investment Company Act of 1940 \$2a, 15 U.S.C. \$80a-2a (1970). See note 12 supra.

111 It is a common rule of statutory interpretation that a statute unambiguous on its face should not be subjected to judicial interpretation. Caminetti v. United States, 242 U.S. 470 (1916); cf. Hamilton v. Rathbone, 175 U.S. 414 (1899).

But cf. Willheim v. Murchison, 342 F.2d 33, 42 (2d Cir.) (Friendly, J.), cert. denied, 382 U.S. 840 (1965): "[A] court should give [the Act] a hospitable reception but ought not expand its words beyond their natural meaning to bring within its sweep a transaction .. . which is not the 'mischief and defect' aimed at by the Act and which it is doubtrul that Congress would have wished to include if it had considered the problem."

11215 U.S.C. $\$ \S 77 a-a a$ (1970).

113 See E.I. du Pont de Nemours \& Co., 34 S.E.C. 531 (1953), overruling Phoenix Sec. Corp., 9 S.E.C. 241 (1941).

To apply to Section 17 (a) of the Investment Company Act the no-sale concept . . . would, in effect, make a vote of security holders a substitute for review under Section 17 (b) and would not in our opinion be an interpretation of Section 17 (a) consistent with the purposes of the declaration of policy in Section 1(b) of the Act.

Id. at 534.

Three considerations should enter in determining whether the "no-sale" rule should extend beyond the 1933 Act to include the 1940 Act. These are: first, the surface similarity between the provisions of the 1933 and 1940 Acts, that is, the fact that in both, antecedent filing with the SEC is required before a transaction can be effected; second, the fact that under the 1933 Act the SEC does not pass upon the accuracy of the registration statement, while under the 1940 Act the SEC must 
The SEC is on a little better ground in reading section 17 (b)'s language, providing an exemption where there is no overreaching "on the part of any person concerned," as supportive of its requirement that there must be fairness in the transaction to parties other than the investment company. Given the ambiguity of the section, this interpretation would be most appropriately judged by reference to the legislative history.

To summarize, then, the SEC's position with respect to both its jurisdiction under section 17 (a) over an exchange of shares pursuant to a merger, and the statutory standard for exemption under section 17 (b), may well have been invalid in the Talley/GTC merger proceeding. On the other hand, the SEC is probably on firmer ground with respect to its interpretation of section 17(d). As in the case of section 17(a), the downstream affiliate can not escape the section's express reach on the basis of legislative history because of section 2(a)'s definition. Further - except for the most strained applications-the SEC's position with regard to this provision would probably be upheld, as it was by Judge Friendly, whenever its reading, even if "overly literal," is "not unnatural." 114

\section{Interpretation and the Changing Background}

Whether the SEC's interpretation of section 17's mandate is valid or not with respect to the legislative history of the Act, the question can independently be posed whether that interpretation is desirable or not in light of developments since the Act's passage. The most striking of these is the growth of the investment company industry, ${ }^{115}$ both in absolute terms and relative to other investors. The SEC's study of investment trusts all but defined open-end companies (mutual funds) as those not holding blocks of securities large enough to influence or control portfolio companies, ${ }^{116}$ and found in practice that where such holdings did exist-usually among closed-end companies-it was very often with an intent to exercise such influence. ${ }^{117}$ Neither is the general rule today. Large holdings are no longer uncommon among mutual funds-particularly not among fund complexes. ${ }^{118}$ On the other hand, large holdings are probably less often obtained with an aim to control or influence

satisfy itself of the fairness of certain transactions; and third, the fact that the policy underlying the "no-sale" doctrine (that a "sale" is a voluntary transaction) seems to obtain under both acts.

114 SEC v. General Time Corp., 407 F.2d 65, 70 n.6 (2d Cir. 1968), cert. denied, 393 U.S. 1026 (1969).

115 See generally SEC, Report on Public Policy Implicatrons of Investment CoMrpany Growtr, H.R. ReP. No. 2337, 89th Cong., 2d Sess. (1966) [hereinafter cited as Public Policy Report].

116 See InVEStaient TruSt STudy, supra note 79, pt. 1, at 18-28.

117 See id. 26, 76-77.

118 Arthur Lipper Corp., Insight: Book Two-Portfolio Holdings . . of Funds (1st quarter 1972). 
portfolio company management. ${ }^{119}$ A further change, although one more nearly a matter of degree, is the felt need for a healthier system of "corporate democracy," ${ }^{20}$ and the increasing calls for greater institutional-investor participation. ${ }^{121}$ The SEC's currently-proposed rules for disclosure by investment companies of their policies with respect to involvement in the affairs of their portfolio affiliates, ${ }^{122}$ may prod them in this direction. Both developments have their impact upon policy choices for the portfolio affiliate problem, the subject of the next part of this Comment.

\section{Policy Considerations for Selecting a Regulatory APPROACH}

\section{A. Evaluating the Basic Approaches}

Out of the various policies calling for effectuation in this area, there have developed three basic regulatory approaches to transactions between investment companies and their insiders and portfolio affiliates. The first of these, the approach of the 1940 Act, as its terms may be best interpreted, is the most stringent. Under this approach, all transactions between "affiliates" and investment companies, with only a few exceptions, which are dealt with elsewhere in the Act or which involve no substantial likelihood of preferential treatment, must be presented to the SEC for advance approval of their fairness to the investment company's shareholders. ${ }^{123}$ A variation on this approach-and, if the legislative history is any guide, the form intended by the drafters of the Act and by Congress ${ }^{124}$-would not require agency scrutiny of transactions with portfolio affiliates.

119 See Wharton Report, supra note 50, at 26; cf. Public Policy Report, supra note 115 , at $308-10$.

120 See Blumberg, The Politicalization of the Corporation, 26 Bus. LAw. 1551 (1971) ; Eisenberg, Access to the Corporate Proxy Machinery, 83 HARv. L. Rev. 1489 (1970); Ratner, The Government of Business Corporations: Critical Reflections on the Rule of "One Share, One Vote," 56 CoRancl L. Rev. 1 (1970); Schwartz, The Public-Interest Proxy Contest: Reflections on Campaign GM, 69 MICH. L. REv. 419 (1971).

121 See, e.g., Landau, Do Institutional Investors Have a Social Responsibility?, 4 INST. INV., July 1970, at 25; cf. Louis, The Mutual Funds Have the Votes, 75 Fortune, May 1967, at 150. See also Comment, Mutual Funds, Portfolio Companies and the Small Investor: The Role of Institutional Influence, 5 CoLum. J.L. \& Soc. Prob. 69 (1969).

122 SEC Investment Company Act Release No. 6853 (Dec. 1, 1971), in [19711972 Transfer Binder] CCH FEd. SEC. L. REP. $\llbracket 78,432$.

123 The SEC's position has been that the transactions must be fair to everyone concerned. See Fifth Ave. Coach Lines, Inc., SEC Investment Company Act Release No. 5214 (Dec. 27, 1967), in [1967-1969 Transfer Binder] CCH FED. SEC. L. REP. I77,522; Bowser, Inc., SEC Investment Company Act Release No. 4842 (Feb. 8, $1967)$, in [1966-1967 Transfer Binder] CCH FED. SEc. L. Rep. $₫ 77,435$. The precise legislative scheme is to prohibit the transactions (Investment Company Act of 1940 $\$ 17,15$ U.S.C. $\$ 80 \mathrm{a}-17$ (a) (1970)) unless an exemption is granted based on SEC determination that the transaction is fair and consistent with the purpose of the investment company and the 1940 Act. See text accompanying notes 5-12 supra.

124 See notes 86-95, 108-09 supra \& accompanying text. 
At the other extreme stand the National Association of Securities Commissioners' 1939 Regulations Governing Investment Trusts, ${ }^{125}$ which were proposed as a form of uniform blue sky law. Apparently, however, because of the passage of the Investment Company Act one year later, which substantially reduced the force behind the movement, these regulations were adopted in only about a dozen states. The approach employed here is to require the investment company's charter to include proscriptions of self-dealing by insiders. Thus, the regulations provide that any "offer or disposal" of investment trust shares is unfair unless the instruments creating the trust are effective to prevent trust insiders-the officers, directors, or trustees-from dealing "for or on behalf of the trust with themselves, as principal or agent or with any corporation or partnership in which they have a financial interest." 120 These regulations further require that instruments of a trust prohibit the "purchase" of the shares of a company, for the portfolio of the trust, where one or more of the fund's officers or directors own beneficially more than one-half of one percent of the company's shares, and such directors together own beneficially more than five percent of the company's shares. ${ }^{127}$ In this respect the regulations seemingly go beyond the 1940 Act which does not, at least in section 17 (a) (1), prohibit investment companies from purchasing on the open market the shares of an affiliate of an affiliated person. ${ }^{128}$

In contrast to the 1940 Act with its exemption procedure, the uniform regulations are less concerned with the fairness of particular transactions but rather require per se prohibitions against certain kinds of transactions or activities of directors. The test appears to be whether there is a substantial likelihood of conflicting demands on the loyalties of the trust's directors or officers. Like section 17 (a) of the 1940 Act, the uniform regulations are concerned with "purchases" of shares under the circumstances set forth, ${ }^{120}$ and due to the absence of any exemption procedure or safety valve to prevent the regulation from going beyond the point of diminishing returns, a stronger argument may be made here that "purchase" should be construed not to include a mere mechanical exchange pursuant to a merger. Such transactions would not come within any test concerned with the potential effect of divided loyalties because the discretion left to the directors or officers as managers of the fund is reduced to a minimum.

125 The uniform regulations, as adopted in New Hampshire, are reprinted in 2 BLuE Sky L. REP. \| 32,613, at 28,502-06 (1969).

126 Id. 28,502 .

127 Id. $28,502-03$.

128 Under the definitions contained in the 1940 Act, a company, 5\% of whose stock is owned by the directors of an investment company, may be referred to as an affiliate of affiliated persons. While $\$ 17$ (a) (1) of the 1940 Act may not reach open market transactions under the circumstances outlined in the text, $\$ 17$ (d) and rule 17d-1 may be applicable.

1292 Brue Sky L. Rep. $\llbracket 32,613$, at 28,502-03 (1969). 
A third regulatory approach, falling somewhere between the two, might be formulated as a "degree-of-involvement" approach. It would concern itself, as do both the 1940 Act and the uniform regulations, with fiduciary self-dealing, and thus would deal with investment company transactions with upstream affiliates, but only where there was a substantial degree of involvement on the part of the investment company in negotiating the terms of the transaction. Such involvement would not be deemed to include the investment company's voting its shares on a question presented to all voting stockholders for approval. Because of the ambiguity necessarily inherent in such a standard, a statute employing this approach would probably provide for prospective exemption of transactions, as does the 1940 Act; a similar standard, geared to protect the shareholders of the investment company, would be appropriate.

Prior to assessing these approaches with respect to the essential policies operating in the area, two rationales occasionally put forward to justify agency scrutiny of transactions with portfolio affiliates may be laid to rest. Both are discreditable, it is submitted, for the reason that they are not related to anything in the nature of investment companies.

It is sometimes suggested that the SEC should prevent investment companies from taking advantage of others through action on inside information that they might receive by virtue of their economic influence with their portfolio affiliates. ${ }^{130}$ Rule $10 \mathrm{~b}-5,{ }^{131}$ however, should be sufficiently robust to deal with abuses of inside information. However, to the extent that the contours of that rule and the section under which it is promulgated are unsettled (in particular, it is unclear whether it could be applied to the fund in the Talley case), ${ }^{132}$ it should be noted that if rule $10 \mathrm{~b}-5$ does not reach what some would characterize as inside information abuses, it can be argued that Congress did not perceive an abuse calling for regulatory action.

A second policy would protect portfolio affiliates from being subjected directly to unfair treatment at the hands of investment companies. The SEC's zeal to eliminate sharp dealing, wherever possible, and upon whatever pretext may be available, is understandable. However,

130 See SEC v. Talley Indus., Inc., 399 F.2d 396, 404 (2d Cir. 1968), cert. devied, 393 U.S. 1015 (1969).

13117 C.F.R. \$240.10b-5 (1972).

132 The Talley situation, if it is to be reached under rule $10 \mathrm{~b}-5$, must clear the hurdles of both the Birnbaum rule, Birnbaum v. Newport Steel Corp., 193 F.2d 461 (2d Cir.), cert. denied, 343 U.S. 956 (1952), not yet without vitality, and the insider requirement. The former may be the less difficult: the Fund, on the basis of its knowledge that Talley planned a takeover bid, purchased GTC shares from unknowing sellers in the market, who could be likely plaintiffs. It is less conceivable, however, that the Fund could be characterized as an "insider" with respect to GTC or-even granting that Talley, by the time it told the Fund of its plans, held a substantial enough block of GTC stock to be labeled an insider-that the information, originating as it did with Talley, could be tagged as "inside" so far as GTC is concerned. On the intricacies of rule $10 \mathrm{~b}-5$, see genterally 1 A. Bromberg, Securities Law: Fraud, SEC Rule 10b-5 (1971). 
countering this position is the fact that any approach which was not applied to other institutional investors and large stockholders might well be construed as unfairly discriminatory. In conjunction with this factor, there is the further consideration of allocation of resources. Thus, given the investment companies' demonstrated penchant for not involving themselves in corporate affairs, ${ }^{133}$ to require close scrutiny of investment company/affiliate relationships would be to commit a great effort to preventing what is in all likelihood a small chance of abuse.

Two other policy goals are more nearly related to the peculiar nature and potential abuses of investment company operations. Therefore, the appropriateness of the three basic regulatory approaches should be determined by their effectiveness in implementing these legitimate policies. The first of these policies is the protection of the investment company's shareholders from losses or unfair treatment at the hands of upstream affiliates-directors, officers, or companies owning substantial amounts of the fund shares-dealing with the fund. The need for such protection was articulated at the hearings on the bill which became the 1940 Act, $^{134}$ and was ultimately recognized by Congress in the Act itself. ${ }^{135}$ One situation clearly within the purview of this policy is that in which directors arrange for the fund to enter into transactions that benefit themselves, the directors, rather than the fund. All three methods of regulation, the 1940 Act, the uniform regulations, and the proposed "degree-of-involvement" approach would apply to prohibit such transactions. But suppose the upstream affiliate is a company rather than a director. In a bargaining situation, where the interests of those dealing on behalf of the investment company are adverse to the interests of those dealing on behalf of the other party to a transaction, the argument that an agency must step in to protect the investment company's shareholders is less than compelling. However, to the extent that one may be justified in hesitating to assume an identity of interests between the investment company's shareholders and its managers ${ }^{136}$ a fair argument can be made for independent scrutiny of these transactions. Apparently not applicable where a company rather than a fund director is the upstream affiliate, the uniform regulations would fail to achieve such a result. On the other hand, the 1940 Act, and the proposed "degree-of-involvement" approach would be effective to insure scrutiny for fair dealing.

133 See generally D. Baum \& N. Strues, The Silent Partners: Instrtutional INVESTORS AND CORPORATE CONTROL (1965).

134 Senate Hearings, supra note 96, pt. 1, at 204 (remarks of Senator Wagner): The testimony today, which I wish Senator Taft had listened to, of the methods used to secure the funds of truckmen, school teachers, domestics, and these absolutely outrageous misrepresentations made to them, which induced them to give up and lose their last pennies, has shown us a state of affairs which we cannot ignore. We have got to devise some means of protecting the people.

(1970).

135 See Investment Company Act of 1940 \$1(b)(2), 15 U.S.C. $\$ 80 a-1(b)(2)$

136 Cf. Investarent Trust Study, supra note 79, pt. 3, at 1027, 1068, 1084-85. 
Suppose finally, that the fund/upstream-affiliate transaction is only one of a large number of similar transactions. In other words, consider the situation in which the affiliate has not arranged any peculiar conditions, but is merely participating on the same terms in a general offer to purchase or sell. Under these circumstances there is little likelihood that the affiliate is benefiting particularly at the expense of the fund, and the investor-protection goal will rarely require SEC review for self-dealing. Under the 1940 Act, however, as distinct from the "degree-of-involvement" approach, many of these transactions will be reviewed by the SEC. Indeed, it is not entirely clear whether the uniform regulations would accept many of these transactions.

A second policy relative to investment companies is the fostering of their involvement in portfolio company affairs. The theory here is that institutional investors with their more significant holdings, possess superior research resources and expertise which may enable them to contribute valuably to portfolio company management. By doing so, they protect their own best interests and, concomitantly, the interests of smaller, less articulate investors. ${ }^{\mathbf{1 3 7}}$

Undeniably, too vigorous pursuit of such a policy might tend to produce undesirable ramifications : closer identification by fund directors with the interests of the portfolio company; increased temptation of fund directors to trade or otherwise take advantage of inside information. These problems aside, however, the involvement-fostering policy argues against SEC scrutiny with its potential for discouragement of dealings between investment companies and their portfolio affiliates. This argument is independent of the previous proposition that review is not necessary in portfolio situations; the threat of review and possible litigation is likely to have the undesirable effect of discouraging more active concern with and participation in portfolio company affairs. Not applicable to investment-company/portfolio-affiliate transactions, the uniform regulations and the proposed "degree-of-involvement" approach do not hinder the involvement-fostering policy. The 1940 Act, on the other hand, at least as administered by the SEC, can present a significant obstacle. An investment company actively participating in portfolio company affairs risks litigation under section 17 (d) and perhaps under section 17 (a) where a transaction not excepted by that section is involved.

It appears from the foregoing analysis that the proposed "degreeof-involvement" approach comes nearest to accommodating the two policies that justify specialized regulation of investment companies. The uniform regulations fail to effectuate the investor-protection policy in the case where there has been bargaining between an investment company and a company owning five percent or more of its stock. The only difficulty with the 1940 Act, as Congress may have intended it to operate, is that it leads to interference with transactions where there has

137 See text accompanying note $95 \&$ text accompanying notes 119-20 supra. 
been a general offering in similar terms and where there is little likelihood that affiliates have engaged in self-dealing. But the 1940 Act as applied by the SEC pays court to the bogus policy of protecting all parties incidentally connected to every transaction the investment company enters. Moreover, by failing to except activities and transactions having little likelihood of insider self-dealing, the Act serves to hinder the involvement-fostering policy. Thus the 1940 Act as presently administered appears the least satisfactory of the alternative methods of regulation.

\section{B. The Effects of Portfolio Scrutiny: Mandate for a New Approach}

So long as transactions with portfolio affiliates are to be scrutinized, as they are under the framework presently maintained by the SEC, irreconcilable conflict will persist between the policy of investor protection (which manifests itself in making dealings between investment company and affiliate uncomfortable) and the policy of encouraging better institutional citizenship in our corporate democracies. This conflict will be accentuated in the years to come, particularly if the effect of decreasing liquidity becomes more manifest. ${ }^{\mathbf{1 3 8}}$ This latter factor will exert pressure on investment companies to retain their positions in portfolio companies even where they are dissatisfied with a portfolio company's management; this more lasting commitment may push the investment companies into greater involvement in portfolio company affairs. Indeed, tomorrow's version of the Talley case may well find the investment company less able to plead non-involvement.

The present state of the law in this area brings two other regrettable side-effects; it makes investment companies into corporate albatrosses, ${ }^{130}$ as hapless portfolio companies find themselves - through no choice of their own-subjected to undue SEC scrutiny, and it potentially has turned a section of an act intended to protect investors of moderate means, the shareholders in investment companies, into a pawn in struggles for control and a weapon for strike-suitors.

This situation could be remedied by amending section $17:$ first, to remove from the definition of "affiliated person," for purposes of section 17 , the portfolio affiliate; second, to make clear that it is solely the interest of the investment company shareholder that is to be considered in weighing applications for exemption; and third, to exempt from the SEC's scrutiny all routine, non-bargained transactions. The last two adjustments, of course, could be accomplished by the SEC through its rulemaking powers.

A more thorough analysis of the policies behind section 17 , and appropriate legislative and administrative steps directed toward achieving those policies, are thus suggested for developing a more rational

${ }^{138}$ See generally Lyons, What Happens When Liquidity Disappears?, 3 INst. INv., Nov. 1969 , at 29.

139 Judge Friendly records that Sterling Precision considered its affiliation with the Equity Corp. "a handicap to its operations." SEC v. Sterling Precision Corp., 393 F.2d 214, 216 (2d Cir. 1968). 
regulatory approach. To this should be added the broader need to reexamine and better articulate national policy with respect to the involvement of institutional investors in the affairs of portfolio companies. ${ }^{140}$ Some thirty years ago, when investment companies were seen as a promising source of venture capital, it was determined that the net benefits to be derived from cultivating that source would outweigh whatever disadvantages were brought with the close involvement of investment companies in the affairs of companies they funded and strongly influenced. ${ }^{141}$ Today, a similar judgment might well be made with respect to the benefits incident to a revitalized corporate democracy. But unless a clear course is set, investment companies can hardly be faulted for preferring not to risk involvement in section 17(d) litigation.

\section{Recommendations for Doing Business Under Talley}

On the assumption that legislative and administrative action can not serve to solve immediate and existing problems, some suggestions are offered with respect to steps portfolio affiliates interested in planning mergers in Talley-type situations might employ to avoid section 17 's impact.

A court challenge to the SEC's interpretation of section 17-particularly, its far-ranging standard for exemptions under section 17 (b)might well succeed, but is unlikely to be brought; businessmen are not likely to risk being the losers in test cases. Therefore, the safest route, the one to be recommended as a matter of course until some change in the law is brought about, is application for an exemption under section 17 (b) and, if appropriate, rule $17 \mathrm{~d}-1$.

The exemption route is straightforward, even if the scope of inquiry prescribed by the SEC may be disputed as being broader than that intended by the Act and as establishing an uncontemplated inconsistency in the treatment of violations of sections 17 (a) and (d). And although few benefits may derive from having obtained an exemption, ${ }^{142}$ the consequence of failure to secure an exemption may be so drastic, including potential voiding of the transaction, ${ }^{143}$ that it might well be unreasonable to fail to apply for exemption. Applications may be filed after the fact, ${ }^{144}$ but the SEC is reluctant to grant retroactive exemptions. The Commission may be willing to exempt the status quo, but not to excuse the transaction occasioning the violation; ${ }^{145}$ or it may

140 See SEC, Institutional Investor Study Report, H.R. Doc. No. 92-64, pt. 5, $92 \mathrm{~d}$ Cong., 1st Sess. 2763 (1971).

141 InvestMent TRUST Study, supra note 79 , pt. 4 , at 369.

142 For example, the parties may still be open to shareholder suits on the ground that the transaction was so unfair as to constitute a breach of fiduciary duty; see Entel v. Allen, 270 F. Supp. 60, 67 (S.D.N.Y. 1967).

143 Investment Company Act of 1940 \$ 47, 15 U.S.C. $\$ 80 \mathrm{a}-46$ (1970).

144 See Fifth Ave. Coach Lines, Inc., SEC Investment Company Act Release No. 5682 (May 20, 1969). The history of the case, indicating after the fact application, appears in 34 Fed. Reg. 7349-50 (1969).

145 Wisconsin Sec. Co., SEC Investment Company Act Release No. 5708 (June $12,1969)$. 
require the parties to rescind the original transaction and to reexecute it after receiving the exemption. ${ }^{148}$

Companies not confident of receiving the SEC's approval, or not willing to take the time to file for an exemption, may wish to try to structure their transactions so as to avoid section 17. Some suggestions follow, with the warning that resort to any of them may tempt the SEC to bring an injunctive-relief action. The further warning should be made that section $17(\mathrm{~d})$ is a serious hazard, as soon as any deliberate structuring-particularly, involving the investment companyenters a transaction.

The first, and simplest, possibility is to arrange the merger, where feasible, with a non-affiliate of the investment company as the survivor. Where a non-affiliate conducts an exchange of shares, section 17 (a) does not operate.

If both $X$ and $Y$, wishing to merge, are portfolio affiliates of investment company $Z$, the first-mentioned alternative is no longer available. It may be that section 17 can nevertheless be avoided by selling $X$ 's assets to $Y$, in exchange for $Y$ 's stock, with a delayed liquidation of $X .^{147}$ ( $Z$ 's participation in the liquidation of $X$ would be exempted under rule $17 \mathrm{a}-5$.) ${ }^{148}$ A significant problem with this operation is that the formally separate transactions-the various steps-may be viewed as really only interrelated parts of a single plan to exchange $X$ stock for that of $Y$ with $Z$ taking part in the exchange. Under this view, and considering the rule of the Talley case, the operation comes within the prohibition of section 17(a). The Supreme Court, however, has recently indicated a reluctance to find statutory violations on the basis of such an analysis. ${ }^{149}$ It is possible further that the concurrent holding of stock in $Y$ by $Z$ and its affiliate $X$ may violate rule $17 \mathrm{~d}-1 ;{ }^{150}$ in this event, the SEC might well decide to look at the broader transaction.

146 Puritan Fund, Inc., SEC Investment Company Act Release No. 6531 (May $18,1971)$. The history of the case, indicating rescision ordered prior to the exemption application, appears in 36 Fed. Reg. 8175 (1971).

147 See Farris v. Glen Alden Corp., 393 Pa. 427, 143 A.2d 25 (1958) (transfer of assets for stock and subsequent liquidation constituted a valid merger). Contra, Hariton v. Arco Electronics, Inc. 40 Del. Ch. 326, 182 A.2d 22 (Ch. 1962), aff'd, 41 Del. Ch. 74, 188 A.2d 123 (Sup. Ct. 1963). See also Orzeck v. Englehart, 41 Del. Ch. 361, 195 A.2d 375 (Sup. Ct. 1963).

14817 C.F.R. $\$ 270.17 a-5$ (1972) provides:

When a company makes a pro rata distribution in cash or in kind among its common stockholders without giving any election to any stockholder as to the specific assets which such stockholders shall receive, such distribution shall not be deemed to involve a sale to or a purchase from such distributing company as those terms are used in section 17(a) of the act.

149 Cf. Reliance Elec. Co. v. Emerson Elec. Co., 404 U.S. 418 (1972) (corporations could not recover under $\$ 16(\mathrm{~b})$ of the 1934 Act profits derived from the sale of shares by shareholders who first sold enough shares to reduce their holdings just below $10 \%$ ).

150 See note 77 supra \& accompanying text. 
Finally, under section $3(\mathrm{a})(3)$ of the $\operatorname{Act}^{151} X$ will very likely be deemed to have become an investment company at the point when more than forty percent of its assets are securities; X's affiliation with $Z$ may then raise a problem under section 12 (d)(1)(A) (i), ${ }^{152}$ one of the Act's anti-pyramiding provisions. Additionally, section $25,{ }^{153}$ dealing with the reorganization of investment companies, would involve the SEC in $X$ 's liquidation, should section 3(a) (3) have operated.

If either $X$ or $Y$ is controlled ${ }^{154}$ by $Z$ the above technique would be ineffective to avoid an immedate clash with section $17(\mathrm{a})$, in that affiliates are prohibited under that section from either selling to or purchasing from companies controlled by the affiliated investment company, any property. In this event, $X$ may try making an exchange offer to $Y$ 's shareholders, with $Z$ agreeing not to accept the exchange offer and retaining a minority interest in $Y$ (or, alternatively, agreeing to sell its $Y$ shares on the market). The risks under these arrangements are that the SEC will find a violation of rule $17 \mathrm{~d}-1$ even in the agreement not to transact business with one another, and, as mentioned in the preceding paragraph, that the concurrent holding of $Y$ stock by $Z$ and its affiliate $X$ may pose a problem under the same rule.

If the techniques and the difficulties suggested here seem farfetched, then they are so only because they reflect the present state of the law respecting portfolio affiliation with investment companies. Indeed the need for reinterpretation, if not thorough revision, could hardly be more evident.

15115 U.S.C. $\$ 80 \mathrm{a}-3(\mathrm{a})(3)$ (1970). See generally Kerr, The Inadvertent Investment Company: Section $3(a)(3)$ of the Investment Company Act, 12 STAN. L. Rev. 29 (1959); Kerr \& Applebaum, Inadvertent Investment Companies-Ten Years After, 25 Bus. LAw. 887 (1970).

15215 U.S.C. $\$ 80 \mathrm{a}-12(\mathrm{~d})$ (1) (A) (i) (1970). Cf. Baldwin Sec. Corp., 39 S.E.C. 498 (1959).

15315 U.S.C. \$80a-25 (1970).

154 Twenty-five percent ownership of another's outstanding voting securities gives rise to a presumption of "control." See 15 U.S.C. $\$ 80 \mathrm{a}-2(\mathrm{a})(9)$ (1970). 